\title{
Contrasting effects of land use legacies on grassland restoration in burnt pine plantations
}

\author{
Katalin Szitár $^{\mathrm{a}, *}$, Gábor Ónodi ${ }^{\mathrm{a}}$, László Somay ${ }^{\mathrm{a}}$, Ildikó Pándi ${ }^{\mathrm{b}}$, Piroska Kucs ${ }^{\mathrm{c},}{ }^{1}$, György Kröel-Dulay ${ }^{\mathrm{a}}$ \\ a Institute of Ecology and Botany, MTA Centre for Ecological Research, 2-4. Alkotmány u., Vácrátót 2163, Hungary \\ b Botanical Garden, Szent István University, 1. Páter Károly u, Gödöllő 2100, Hungary \\ c Eötvös Loránd University, 1-3. Egyetem tér, Budapest 1053, Hungary
}

\section{A R T I C L E IN F O}

\section{Article history:}

Received 30 March 2016

Received in revised form 28 July 2016

Accepted 2 August 2016

Available online $\mathrm{xxx}$

\section{Keywords}

Common milkweed

Ecological filters

Facilitation

Nurse effect

Plantation forest

Post-fire recovery

\begin{abstract}
A B S T R A C T
Legacies of previous land use may affect ecosystem recovery after the specific land use has ceased. Determining which legacies do limit ecosystem recovery is critical to perform effective ecological restoration. Pine (Pinus spp.) plantations have replaced various natural habitats including woodlands, shrublands and grasslands worldwide. Following pine tree removal, the restoration of these habitats may be complicated by pine plantation legacies. In this study, we tested three factors that may constrain grassland recovery in a former pine plantation following burning in an inland sand dune region in Hungary. We evaluated the effects of pine litter removal, native grass seeding and the presence of invasive Asclepias syriaca on vegetation composition during seven years of recovery using generalised linear mixed effect models and non-metric multidimensional scaling. We found that litter removal did not facilitate grassland regeneration. Grass seeding led to a fast recovery of grass cover, but negatively affected the abundance of unseeded target species. The presence of Asclepias had only transient effects on seeded grasses but positively affected unseeded target species richness. We conclude that sand grasslands have high restoration potential in burnt pine plantations despite the presence of several land use legacies. We found no evidence that pine litter or the presence of Asclepias would negatively influence grassland recovery, which implies that their removal is not necessary for a successful restoration. We suggest that moderate seeding densities of native grasses need to be applied to avoid the suppression of other target species.
\end{abstract}

(C) 2016 Published by Elsevier Ltd.

\section{Introduction}

Land use legacies are changes in ecosystem conditions that persist even after the specific land use has ceased (Foster et al., 2003). Previous land use may affect the recovery of targeted ecosystems during restoration via altered propagule availability of species, and abiotic and biotic constraints on community re-assembly (Corbin and D'Antonio, 2012). Legacies are generally viewed in the context of regeneration limitation (Corbin and D'Antonio, 2004; Foster et al., 2003 ) but their potential positive effects on recovery may also be notable (Jiang et al., 2010; Morris et al., 2014). Identifying important legacies that should be mitigated or utilised during restoration is critical to perform effective ecological restoration.

Exotic pine species (Pinus spp.) are widely planted for timber production in many parts of the world (Richardson and Rejmánek, 2004). Due to the broad ecological tolerance of several pine species (Leege

\footnotetext{
* Corresponding author at: Institute of Ecology and Botany, MTA Centre for Ecological Research, 2-4. Alkotmány u., Vácrátót 2163, Hungary.

Email addresses: szitar.katalin@okologia.mta.hu (K. Szitár); onodi.gabor@, okologia.mta.hu (G. Ónodi); somay.laszlo@okologia.mta.hu (L. Somay); pandi. ildiko@gmail.com (I. Pándi); piroska.kucs@gmail.com (P. Kucs); kroel-dulay. gyorgy@okologia.mta.hu (G. Kröel-Dulay)

${ }^{1}$ Present address: 69. Thököly út, Budapest 1146, Hungary.
}

and Murphy, 2000), pine plantations occupy not only previous native forest habitats but also former shrublands and grasslands. Native grasslands deliver important ecosystem services that plantations cannot provide, such as long term carbon storage and livestock production (Naidoo et al., 2008). They may also have exceptionally diverse flora and fauna (Pykälä, 2003), therefore the restoration of these habitats is of high conservation priority (Habel et al., 2013). The success of grassland restoration in former pine stands depends on the mitigation of pine plantation legacies that act as regeneration barriers (Bisteau and Mahy, 2005). Filter-based community assembly models suggest that environmental, dispersal and biotic ecological filters may be altered during land use change and they may need to be mitigated to reach favourable community composition (Hulvey and Aigner, 2014).

With the presence of pines, the originally treeless communities experience major changes in environmental conditions such as altered radiation (Cseresnyés et al., 2006), nutrient cycling (Farley and Kelly, 2004) and hydrological regime (Holmes et al., 2000). Dickie et al. (2014) observed major changes in soil attributes caused by $\mathrm{Pi}$ nus contorta invasion into native grasslands in New Zealand. They reported increased available nitrogen and phosphorus content and bacterial dominance. In contrast, several studies detected no major difference in soil attributes between former pine plantations and natural vegetation a few years after pine removal and concluded that soil characteristics did not interfere with regeneration (Szitár et al., 2014; Zaloumis and Bond, 2011). Pine 
litter may be a longer-acting factor due to its slow decomposition rates caused by high $\mathrm{C} / \mathrm{N}$ ratio and high lignin content of pine needles (Taylor et al., 1989). The thick pine litter layer operates as a physical barrier to seed bank formation (Pywell et al., 2002) and germination (Navarro-Cano et al., 2010). Pine litter may also change disturbance regime by increasing fire frequency and intensity (Cseresnyés et al., 2006). Therefore, many authors suggest that pine litter should be removed as part of an effective restoration (Navarro-Cano et al., 2010; Sturgess and Atkinson, 1993).

Pine plantations alter vegetation composition in former grasslands (Szitár et al., 2014). Disturbance associated with the establishment of plantations promotes early-seral annuals (Maestre and Cortina, 2004), while altered light conditions favour forest herb establishment (Bremer and Farley, 2010; Halpern et al., 2012). Pine plantations have lower grassland species richness and abundance than former grasslands both in the aboveground vegetation and in the seed bank (Piqueray et al., 2011). The extent of seed bank depletion depends on several factors including time elapsed since afforestation, seed persistence in the soil and seed rain (Cuevas and Zalba, 2010). Native species can recolonize degraded habitats but it is a slow process operating at a decadal time scale even when available propagule sources are present in the surroundings (Catling and King, 2007). Thus, native seed addition following pine removal is often recommended overcoming dispersal limitation (Holmes et al., 2000; Piqueray et al., 2011). With the reintroduction of dominant grass species one can restore the main structure and functions of grassland communities. Native grasses may also facilitate the establishment of other target species (Gasque and Garcıá-Fayos, 2004).

Plantation forests usually have increased richness of exotic species (Becerra and Simonetti, 2013). Fire may further promote invasion by temporarily increasing the availability of nutrients in the soil (Nuñez and Raffaele, 2007) or by breaking seed dormancy of invasive species (Mojzes and Kalapos, 2015). Pinus removal may also help the invasion of other non-native species (Dickie et al., 2014). Exotic species can be either 'drivers' of ecosystem processes by significantly suppressing native species in the invaded community or 'passengers' by simply taking advantage of environmental changes (MacDougall and Turkington, 2005). The distinction between the two roles is important, as restoration efforts need to focus primarily on 'driver' exotic species to mitigate their adverse ecological effects.
In 2007, pine plantations within a protected area in central Hungary were killed by a wildfire. Based on a five-year vegetation monitoring campaign, we found that the non-native common milkweed (Asclepias syriaca L., hereafter referred to as Asclepias) dominated recovering grasslands. Török et al. (2003) list this species among the most frequent alien species in Hungary, but the observed effects of Asclepias on native species are contradictory (Gallé et al., 2015; Kelemen et al., 2016; Szitár et al., 2014). Improved understanding of the impact of Asclepias during vegetation recovery is necessary for planning adequate grassland restoration.

In this study, our objective was to test experimentally three major factors that may constrain the restoration of open sand grasslands in former pine plantations in central Hungary following burning and clear felling in 2007. Our specific questions were the following: (1) Does the removal of pine litter facilitate grassland recovery? (2) Does the seeding of native grasses enhance the regeneration of open sand grasslands? (3) Does the presence of Asclepias affect the regeneration of grassland vegetation?

\section{Material and methods}

\subsection{Study site and species}

The study site is located in the Kéleshalom Nature Reserve in the Pannonian biogeographic region of Hungary in Central Europe $\left(46^{\circ} 23^{\prime} \mathrm{N}, 19^{\circ} 19^{\prime} \mathrm{E}\right)$. The site is 60 ha in area (Fig. 1), composed of inland sand dunes with an elevation range between 140 and $148 \mathrm{~m}$ a.s.l. It is covered by poorly developed coarse-textured soil with sand content over 90\% and humus content below 1\% (Szitár et al., 2014). The climate is continental with a minimum monthly mean air temperature of $-2{ }^{\circ} \mathrm{C}$ in January and a maximum monthly mean of $22{ }^{\circ} \mathrm{C}$ in July (Szitár et al., 2014). Mean annual precipitation is $550-600 \mathrm{~mm}$.

The natural vegetation of the region is Pannonian forest steppe with a mosaic of open sand grasslands, mesic sand grasslands, and poplar-juniper woodlands (Szitár et al., 2014). Open grasslands are typically situated on dune tops and sides, while mesic grasslands and woodlands characterize interdune depressions. Open sand grassland (Festucetum vaginatae danubiale) is a Pannonian endemic semi-arid community bound to nutrient-poor, coarse-textured calcareous sand (Kovács-Láng

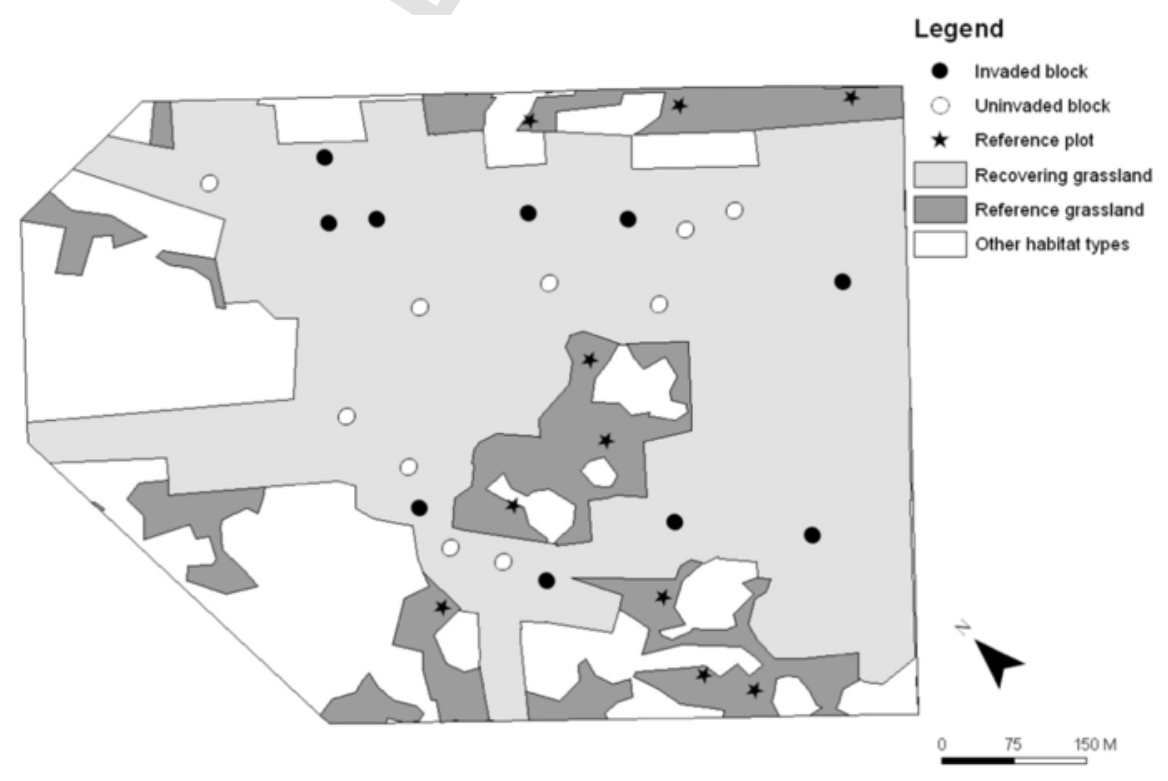

Fig. 1. Map of the study site showing the position of treatment blocks and reference sampling plots. Other habitat types stand for woody patches. 
et al., 2000). Two perennial bunchgrasses, Festuca vaginata W. et K. and Stipa borysthenica Klokov, co-dominate the vegetation interspersed with subordinate perennial herb species. Due to unfavourable soil and geomorphological conditions, a major part of the precipitation cannot be utilised by the vegetation. Aboveground vegetation cover therefore rarely exceeds $30-50 \%$, while plant roots form a more closed layer belowground. Open sand grasslands are self-sustaining communities usually left unmanaged for economic reasons.

According to aerial photographs of the area from the 1950s, vegetation of the study site was a near-natural forest steppe mosaic before pine plantations were established in the 1960s and 1970s. Planted pine species were Austrian pine (Pinus nigra Arnold) and Scots pine ( $P$. sylvestris L.), which are non-native in the study region. Narrow strips (3-5 m wide) of natural sand grasslands were left unplanted among the forestry units. These remnants may serve as potential propagule sources for native species. Understory vegetation of pine plantations is very scarce with few specimens of natural grassland species, and exotic and native weeds (Szitár et al., 2014). In July 2007, a wildfire burnt the study site. The surface fire killed pines and consumed the $5-10 \mathrm{~cm}$ pine litter on the soil surface. Later, needles of killed pines fell down and formed a secondary litter layer of 1-2 cm depth. Dead trees were removed from the area by the beginning of the experiment in 2008. Spontaneous post-fire regeneration of pines was not observed. Before the fire, the study site was partly occupied by the invasive common milkweed (Asclepias syriaca L.). Average common milkweed cover ranged between 11.2 and $20.8 \%$ in invaded plots between 2008 and 2014.

\subsection{Experimental design and sampling}

In autumn 2008, 20 treatment blocks of $3 \times 3 \mathrm{~m}$ were established in the study site (Fig. 1). Ten blocks were placed in stands that were invaded by Asclepias and ten were placed in stands free of common milkweed invasion (hereafter referred to as uninvaded). Blocks were placed in dune tops and sides above $142 \mathrm{~m}$ a.s.l. because an earlier study showed that open sand grasslands are located above this elevation at the site (Szitár et al., 2014). Blocks were at least $40 \mathrm{~m}$ apart from each other. Each block consisted of four $1 \mathrm{~m} \times 1 \mathrm{~m}$ plots with the following treatments: seeding, litter removal, seeding plus litter removal, and untreated control. Plots within blocks were separated by $1 \mathrm{~m}$ buffer zones.

In autumn 2008, litter was removed with a hand rake in litter removal and in seeding plus litter removal plots. As the vegetation was very scarce at the beginning of the experiment, litter mainly consisted of pine litter. In seeded plots, a mixture of the two dominant perennial grass species of sand grasslands, Festuca vaginata (hereafter referred to as Festuca) and Stipa borysthenica (hereafter referred to as Stipa), were seeded as these two species often co-dominate sand grasslands (Kovács-Láng et al., 2000). Grass caryopses (hereafter referred to as seeds) were hand collected in June 2008 in a neighbouring part of the reserve covered by natural vegetation. Seeds were sown without any previous seedbed preparation. Festuca was broadcast-seeded on the soil surface at a density of $1 \mathrm{~g} \mathrm{~m}^{-2}$ (approx. 1500 seeds $\mathrm{m}^{-2}$ ). Stipa seeds were pushed into the soil one-by-one by hand at a density of $1.3 \mathrm{~g} \mathrm{~m}^{-2}\left(100\right.$ seeds $\left.\mathrm{m}^{-2}\right)$. Seeds did not get any post-seeding treatment.

The percentage cover of each vascular species was estimated by visual inspection every year in June between 2008 and 2014, and the seedling number of seeded grasses was counted in 2009. In June 2014, ten reference grassland stands were selected within the study site (Fig. 1). Although these patches were also burnt, they were considered to be natural since fire does not significantly affect the vegetation of these grasslands (Ónodi et al., 2014). A $1 \times 1 \mathrm{~m}$ plot was used for gathering reference vegetation data in each stand. In the reference grassland plots, cover data were collected in June 2014.

\subsection{Data analysis}

The effect of seeding, litter removal, invasion (i.e. the presence of Asclepias) and year were assessed on the following response variables: seedling number and cover of Festuca and Stipa, species richness and cover of unseeded target species. Seedling number of the two seeded species was evaluated based on the data from 2009. The other response variables were assessed throughout the study period. Target species were defined based on a regional study (Csecserits et al., 2011) that published a list of species characteristic to remnant natural vegetation in the region (Appendix A). Nomenclature follows Király (2009).

Statistical analyses were performed using $\mathrm{R}$ version 2.15.2 (R Core Team, 2012). Linear mixed effects models (LME) and generalised linear mixed effects models (GLMM) were applied to investigate the differences in response variables among treatments by using lme4 (Bates et al., 2014) and nlme packages (Pinheiro et al., 2012). Seeding, litter removal, invasion and year were treated as fixed categorical explanatory variables, while plots within blocks were treated as nested random effects in the models. Cover data were square root transformed to meet assumptions of normality and homoscedasticity. Species richness and seedling numbers were analysed using GLMM models with Poisson error distribution and identity link function. Significance of fixed factors was based on Type II Wald chi-square tests.

Effects of seeding on seedling number and cover of Festuca and Stipa were clear, as unseeded plots did not harbour any specimens of these species in 2009. Therefore, in order to meet test assumptions, unseeded plots were excluded from the analyses. In case of significant interactions between fixed factors, post hoc pairwise comparisons between treatments were implemented using Tukey HSD tests and the multcomp package (Hothorn et al., 2008). We conducted several significance tests and controlled for the false discovery rate following Benjamini and Hochberg (1995). Means and standard errors reported in figures and in the text are based on untransformed data. Data on reference grasslands were not included in the statistical analyses, but their means are shown in the figures for reference.

We applied non-metric multidimensional scaling (NMDS) to visualize the temporal shifts in vegetation composition by plotting treatment plot averages between 2008 and 2014 and the average of reference grassland plots in 2014. Bray-Curtis was used as distance metric with square root transformation and Wisconsin double standardization of percentage cover data. For this analysis, the vegan package was used (Oksanen et al., 2012).

\section{Results}

Festuca and Stipa seedlings emerged in high numbers in seeded plots in 2009 (Fig. 2a and b). In seeded plots, Festuca and Stipa reached an average germination rate of $6.5 \%$ and $38.4 \%$, respectively (mean seedling numbers were 114.2 and 38.4 for Festuca and Stipa, respectively). Unseeded plots did not contain any seedlings of seeded species. The presence of the invasive Asclepias did not influence the seedling number of either species (Table 1). Litter removal reduced seedling number of Festuca by $19.8 \%$ compared to that in plots without litter removal, but had no effect on the seedling number of Stipa.

Both the presence of Asclepias and litter removal affected the cover of Festuca (Table 1). It was significantly lower in the presence of Asclepias in 2012 ( $\mathrm{z}=-4.81, \mathrm{P}<0.01$; Fig. 3a). Festuca cover increased in invaded and uninvaded plots until the third and fourth year 

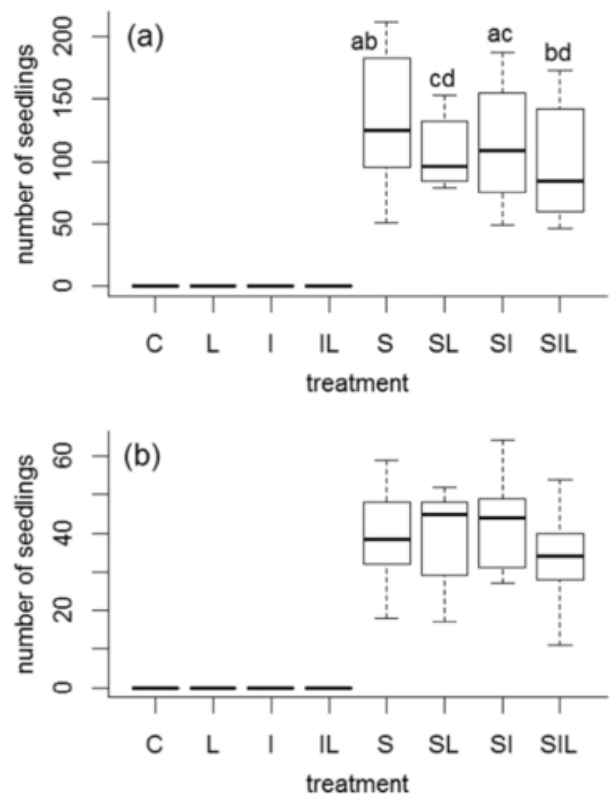

Fig. 2. Boxplot of average seedling number of (a) Festuca vaginata and (b) Stipa borysthenica in treatment groups one year after seeding and litter removal (2009). Different letters indicate statistically different $(\mathrm{P}<0.05)$ means among treatments. Means of unseeded plots are shown without statistical tests as these harboured no seedlings and were excluded from the analyses. Abbreviations for treatments: $\mathrm{C}$ - untreated control; $\mathrm{L}$ - litter removal; $\mathrm{S}$ - seeding; I - invasion (i.e. the presence of Asclepias).

after seeding, respectively. The cover of Festuca was lower in plots with litter removal compared to plots without litter removal in 2009 $(\mathrm{z}=-3.62, \mathrm{P}=0.020)$. In 2011 and 2012, there was a dieback of this species, and the reduction went on even in the last year of the experiment. The direction of change is consistent with the low abundance of the species found in the reference plots in 2014. Spontaneous establishment of Festuca was negligible during the seven years of the study; average cover in unseeded plots was $0.3 \%$ in 2014 compared to $15.4 \%$ cover in seeded plots.

The cover of Stipa showed a steady increase throughout the experiment in seeded plots (Fig. 3b). Although the average cover of Stipa remained below that of Festuca even in 2014, Stipa cover detected in reference plots was exceeded in seeded plots by 2014. Stipa cover was higher in the presence of Asclepias in $2011(\mathrm{z}=4.28, \mathrm{P}<0.01)$. We detected spontaneous establishment of Stipa in unseeded plots from 2009 , but its average cover in unseeded plots remained low compared to that in seeded plots even in 2014 ( $1.4 \%$ and $17.45 \%$, respectively).

Species richness of unseeded target species increased through time in each treatment (Fig. 4a). However, seed addition of Festuca and Stipa had a negative effect on the richness of unseeded target species, and resulted in lower values in seeded plots, with significant differences between seeded and unseeded plots in 2011 and 2012 ( $\mathrm{z}=-3.97, \mathrm{P}<0.01 ;$ and $\mathrm{z}=-3.61, \mathrm{P}=0.015$, respectively).

Plots invaded by Asclepias had a significantly higher number of unseeded target species than uninvaded plots (Table 1). Invaded plots without seeding reached the richness of target species of the reference grassland by 2014. Litter removal did not have any significant effect on unseeded target species richness (Table 1). Grass seeding reduced the cover of unseeded target species each year except for 2010 (2009: $\mathrm{z}=-3.85, \mathrm{P}<0.01 ; 2011: \mathrm{z}=-5.09, \mathrm{P}<0.01 ; 2012$ : $\mathrm{z}=-4.24, \mathrm{P}<0.01 ; 2013: \mathrm{z}=-3.67, \mathrm{P}=0.016 ; 2014: \mathrm{z}=-4.17$, $\mathrm{P}<0.01$; Fig. 4b). The cover of unseeded target species was affected neither by Asclepias invasion nor by litter removal (Table 1).

Non-metric multidimensional scaling of percentage vegetation data shows that all treatment groups shifted gradually toward the reference
Table 1

Results of statistical tests of fixed effects from linear mixed effects models (LME) and generalised linear mixed effects models (GLMM). Significant results $(\mathrm{P}<0.05)$ are shown in bold.

\begin{tabular}{|c|c|c|c|}
\hline Variables and effects & df & F or Chisq & P adj \\
\hline \multicolumn{4}{|l|}{ Seedling number of Festuca vaginata in 2009} \\
\hline Invasion & 1 & 1.25 & 0.488 \\
\hline Litter removal & 1 & 36.77 & $<0.001$ \\
\hline Invasion $\times$ litter removal & 1 & 4.75 & 0.087 \\
\hline \multicolumn{4}{|l|}{ Seedling number of Stipa borysthenica in 2009} \\
\hline Invasion & 1 & 0.01 & 0.963 \\
\hline Litter removal & 1 & 5.45 & 0.065 \\
\hline Invasion $\times$ litter removal & 1 & 4.63 & 0.087 \\
\hline \multicolumn{4}{|l|}{ Cover of Festuca between 2008 and 2014} \\
\hline Invasion & 1 & 0.34 & 0.812 \\
\hline Litter removal & 1 & 6.51 & 0.065 \\
\hline Year & 6 & 273.04 & $<0.001$ \\
\hline Invasion $\times$ litter removal & 1 & 3.72 & 0.162 \\
\hline Invasion $\times$ year & 6 & 7.65 & $<0.001$ \\
\hline Litter removal $\times$ year & 6 & 7.50 & $<0.001$ \\
\hline Invasion $\times$ litter removal $\times$ year & 6 & 0.81 & 0.812 \\
\hline \multicolumn{4}{|l|}{ Cover of Stipa between 2008 and 2014} \\
\hline Invasion & 1 & 4.38 & 0.129 \\
\hline Litter removal & 1 & 0.07 & 0.894 \\
\hline Year & 6 & 298.75 & $<0.001$ \\
\hline Invasion $\times$ litter removal & 1 & 3.37 & 0.181 \\
\hline Invasion $\times$ year & 6 & 4.64 & $<0.001$ \\
\hline Litter removal $\times$ year & 6 & 1.15 & 0.586 \\
\hline Invasion $\times$ litter removal $\times$ year & 6 & 0.68 & 0.873 \\
\hline \multicolumn{4}{|c|}{ Species richness of unseeded target species between 2008 and 2014} \\
\hline Seeding & 23 & 140.33 & $<0.001$ \\
\hline Invasion & 23 & 43.51 & 0.024 \\
\hline Litter removal & 23 & 17.83 & 0.894 \\
\hline Year & 41 & 343.74 & $<0.001$ \\
\hline Seeding $\times$ invasion & 9 & 15.78 & 0.161 \\
\hline Seeding $\times$ litter removal & 9 & 7.52 & 0.812 \\
\hline Invasion $\times$ litter removal & 10 & 11.32 & 0.586 \\
\hline Seeding $\times$ year & 18 & 36.07 & 0.025 \\
\hline Invasion $\times$ year & 18 & 27.70 & 0.129 \\
\hline Litter removal $\times$ year & 18 & 10.19 & 0.963 \\
\hline Seeding $\times$ invasion $\times$ litter removal & 3 & 3.06 & 0.610 \\
\hline Seeding $\times$ invasion $\times$ year & 8 & 8.06 & 0.669 \\
\hline Seeding $\times$ litter removal $\times$ year & 8 & 5.98 & 0.866 \\
\hline Invasion $\times$ litter removal $\times$ year & 8 & 5.13 & 0.894 \\
\hline Seeding $\times$ invasion $\times$ litter removal $\times$ year & 6 & 2.40 & 0.957 \\
\hline \multicolumn{4}{|c|}{ Total cover of unseeded target species between 2008 and 2014} \\
\hline Seeding & 1 & 89.86 & $<0.001$ \\
\hline Invasion & 1 & 1.78 & 0.449 \\
\hline Litter removal & 1 & 0.80 & 0.671 \\
\hline Year & 6 & 62.05 & $<0.001$ \\
\hline Seeding $\times$ invasion & 1 & 1.65 & 0.361 \\
\hline Seeding $\times$ litter removal & 1 & 0.26 & 0.873 \\
\hline Invasion $\times$ litter removal & 1 & 1.09 & 0.600 \\
\hline Seeding $\times$ year & 6 & 14.49 & $<0.001$ \\
\hline Invasion $\times$ year & 6 & 7.92 & $<0.001$ \\
\hline Litter removal $\times$ year & 6 & 1.76 & 0.894 \\
\hline Seeding $\times$ invasion $\times$ litter removal & 1 & 0.67 & 0.610 \\
\hline Seeding $\times$ invasion $\times$ year & 6 & 2.10 & 0.087 \\
\hline Seeding $\times$ litter removal $\times$ year & 6 & 0.47 & 0.894 \\
\hline Invasion $\times$ litter removal $\times$ year & 6 & 0.13 & 0.976 \\
\hline Seeding $\times$ invasion $\times$ litter removal $\times$ year & 6 & 0.98 & 0.747 \\
\hline
\end{tabular}

grassland during the study period (Fig. 5). Trajectories based on yearly mean treatment scores are positioned according to the presence of seeded species in seeded plots and the presence of Asclepias in invaded plots. Seeded and unseeded plots separated most clearly, and the centroids of seeded plots shifted gradually closest toward the reference. Seeded grasses dominated seeded plots throughout the experiment. Unseeded plots had high cover of annuals such as Conyza canadensis and Salsola kali at the beginning of the study, and Med- 

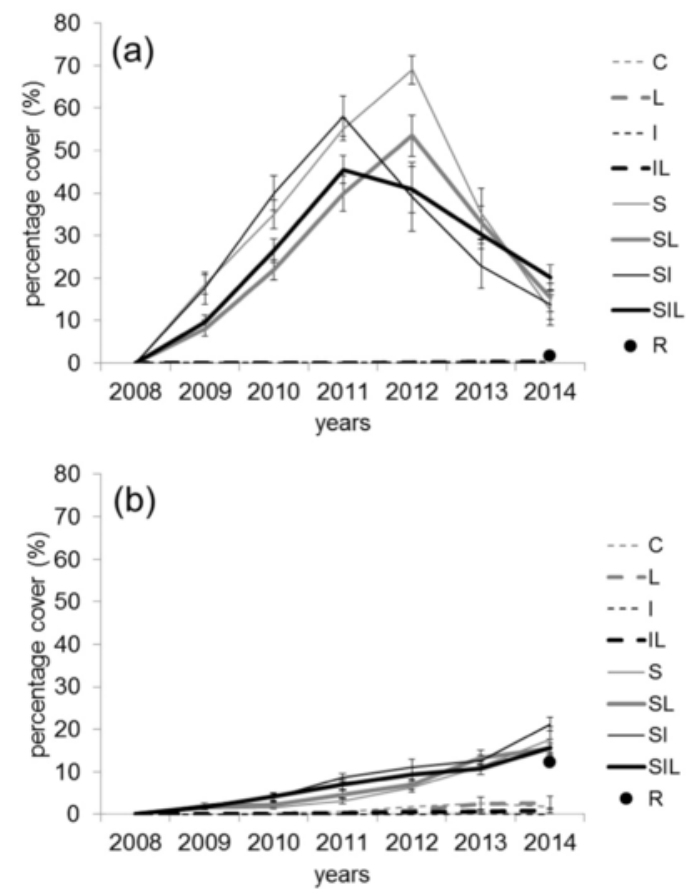

Fig. 3. Average cover $( \pm \mathrm{SE})$ of (a) Festuca vaginata and (b) Stipa borysthenica in treatment plots between 2008 and 2014. For abbreviations see Fig. 2. R denotes reference grassland.

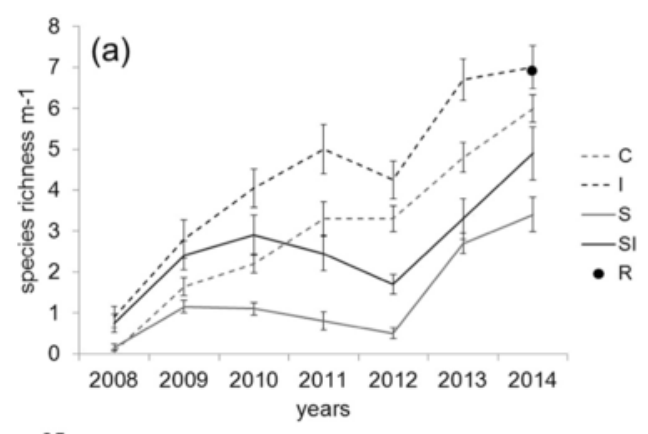

25

(b)

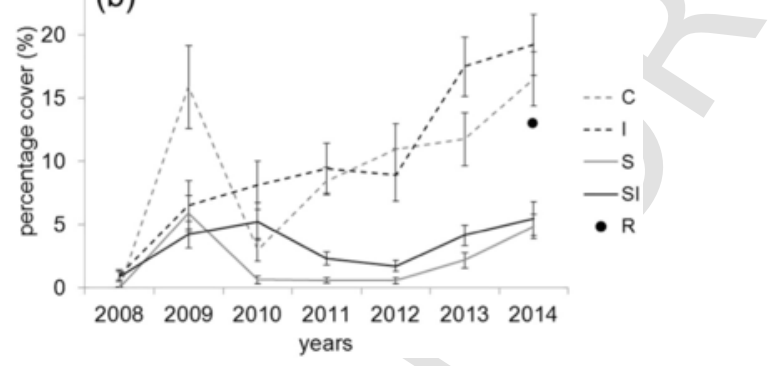

Fig. 4. (a) Richness $( \pm \mathrm{SE})$ and (b) cover $( \pm \mathrm{SE})$ of target species characteristic to natural habitats of the region in treatment plots between 2008 and 2014. As litter removal had no significant effect on the abundance of target species, data from plots with and without litter were combined to create the figures. For abbreviations see Figs. 2 and 3.

icago minima, Arenaria serpyllifolia, and Bromus squarrosus at the end of the experiment. In case of seed addition, invaded plots separated from uninvaded plots due to the sparse presence of unseeded species and high cover of Asclepias. Litter removal had no effect on overall vegetation composition.

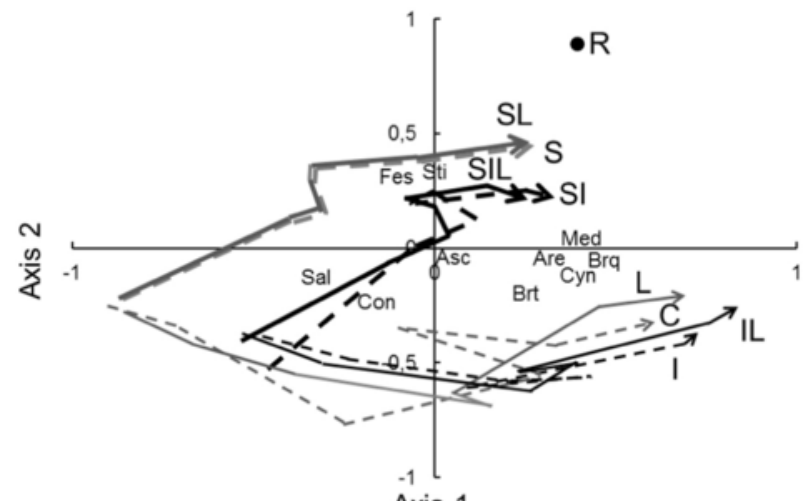

Axis 1

Fig. 5. Ordination diagram of non-metric multidimensional scaling (NMDS) of percentage cover data of treatment plots between 2008 and 2014 and that of reference grassland from 2014. Bray-Curtis was used as distance metric with square root transformation and Wisconsin double standardization of the data. Final stress is 0.241 . Trajectories show temporal shifts of mean treatment scores. For abbreviations of treatments see Figs. 2 and 3. The diagram shows cover weighted average scores of the 10 most abundant species. Abbreviations for species are Are: Arenaria serpyllifolia, Asc: Asclepias syriaca, Brq: Bromus squarrosus, Brt: B. tectorum, Con: Conyza canadensis, Cyn: Cynodon dactylon, Fes: Festuca vaginata, Med: Medicago minima, Sal: Salsola kali, Sti: Stipa borysthenica.

\section{Discussion}

\subsection{Effects of pine litter removal}

Pine litter removal did not affect the recovery of open sand grasslands in our study in terms of the abundance of unseeded target species. This contrasts with the findings of Navarro-Cano et al. (2010) and Walker et al. (2004) who found positive effects of pine litter removal on target species abundance. Boydak (2004) suggests that pine litter depth of $2-4 \mathrm{~cm}$ is an optimal amount for restoration as it does not prevent seedling germination, but does increase seedling survival by reducing evapotranspiration and competition. The lack of negative effects of pine litter in our case may also be attributed to the reduced amount of litter as fire consumed the original thick litter layer and the new layer of pine needles resulting from the fall of dead leaves after the fire was only $1-2 \mathrm{~cm}$ deep.

The only observed effect of litter removal was a transient reduction in Festuca seedling density in the first year of the experiment. This particular year (2009) had below-average precipitation in the growing season ( $246 \mathrm{~mm}$ compared to the long-term mean of $300-350 \mathrm{~mm}$ ), indicating that litter may be favourable in dry years by mitigating adverse hydrological conditions in the soil. The presence of pine litter did not affect Stipa emergence. Similarly, Navarro-Cano et al. (2009) showed that $1.6 \mathrm{~cm}$ deep pine litter did not influence $S$. tenacissima seedling emergence under optimal water supply. Sturgess and Atkinson (1993) suggest that litter layer of up to 20 years old pine plantations can be left in situ as it does not hamper vegetation recovery in coastal sand dunes. On the other hand, thicker primary pine litter layer may be a long lasting pine plantation legacy that has unfavourable effects for germination of native species (Navarro-Cano et al., 2010).

Prescribed burning is a commonly used method to eliminate conifer litter following tree removal (Halpern et al., 2012). The effects of burning depend on fire intensity, species tolerance to fire, and regeneration ability after fire (Funk and McDaniel, 2010). The increase in available nutrients following burning may also promote target and non-target species differently (Sturgess and Atkinson, 1993). Fire is unnecessary when altered light conditions by tree removal alone effectively assist re- 
generation (Halpern et al., 2012). Although fire is not part of the natural disturbance regime, low intensity fire does not impair open sand grasslands in the region (Ónodi et al., 2014). Therefore, prescribed burning to remove litter layer can be beneficial to accelerate grassland recovery following tree removal.

\subsection{Effects of seeding native dominant grasses}

Seeding of the two tussock grasses Festuca and Stipa had a large impact on vegetation recovery. Seed addition enhanced the regeneration of open sand grassland in terms of the abundance of seeded species suggesting low propagule availability of native grasses. Similarly, Navarro-González et al. (2013) found a strong land use legacy of pine plantations as a propagule limitation of native oak species in South Africa. Without grass seeding, early-successional annual species dominated the vegetation throughout the experiment. The cover of seeded species rapidly exceeded the cover in reference plots after seeding, but this may partly reflect the low cover of Festuca in reference plots. The shift from Festuca to Stipa dominance we observed during the study is the usual successional pathway in this grassland (Fekete and Tuba, 1982). The cover decline of Festuca after 2011 may be related to either self-thinning (Fekete and Tuba, 1982) or environmental conditions, as both 2011 and 2012 had below-average precipitation $(433 \mathrm{~mm}$ and $480 \mathrm{~mm}$, respectively, compared to the long-term mean of 550-600 mm). In contrast, Stipa gradually increased in cover throughout our study period and was not impacted by drought. Festuca has both lower dispersal capacity and lower regeneration potential following unfavourable weather conditions than Stipa (Kröel-Dulay et al., 2008). Spontaneous establishment in unseeded plots remained negligible during our study, especially in case of Festuca. This indicates dispersal limitation of the seeded grasses at a nearly decadal time scale in spite of the proximity of remnant vegetation.

As an adverse side effect of seeding, seeded grasses negatively affected the establishment of unseeded target species in terms of both richness and cover. Native species promoted by restoration interventions can impede community assembly especially if they are highly competitive and inhibit colonization of other species (Halpern et al., 2016). The outcome of interactions between seeded species and other target species also depends on the abiotic conditions of the habitat. Seeding tussock grasses can minimize the effects of harsh environments for other species compared to open microsites in arid and semi-arid regions (Gasque and Garciá-Fayos, 2004). However, facilitative effects are expected to be outweighed by competition when stress for a limiting resource is extremely high (Maestre et al., 2009). In our study, however, even the extremely high annual precipitation of $2010(1183 \mathrm{~mm})$, which was double the long-term average, did not increase the abundance of unseeded target species in seeded plots. This suggests that the competitive effect of seeded grasses was not the primary driver for unseeded targets. Instead, grass seeding may have reduced space available for establishment.

Our findings underline the importance of seed addition as an effective management option that accelerates the recovery of the grassland matrix within a relatively short time. The applied seeding density of grasses may influence the outcome of grass-herb interactions. Therefore, if the goal is to restore vegetation composition, lower seeding density of grasses should be applied (Dickson and Busby, 2009).

\subsection{Effects of the presence of invasive Asclepias syriaca}

Many studies have provided evidence that invasive species may hinder native species establishment (Adams and Galatowitsch, 2008). Asclepias is a tall-statured species that overgrows grassland species. Its share of the total vegetation cover in invaded control plots was $86.6 \%$
$(14.6 \%$ out of $16.9 \%)$ at the start and $38.8 \%(19.4 \%$ out of $50 \%)$ at the end of the study. Despite this substantial contribution to the overall vegetation, the presence of common milkweed did not have any major effect on the establishment of the dominant grasses. We observed a transient positive effect of Asclepias on Stipa cover and a transient negative effect on Festuca cover.

The presence of Asclepias caused a small but significant increase in the richness of unseeded target species. In an earlier study on the same site, Szitár et al. (2014) did not find any correlation between milkweed cover and the abundance of colonizing natural grassland species five years following the wildfire. In the study region, droughts are common in summer; therefore, shade created by a common milkweed canopy can have nurse effect by mitigating adverse microclimatic conditions and helping the germination and early establishment of target species. Furthermore, competition between Asclepias and other species for water may be limited as common milkweed is able to exploit unused resources by penetrating deeper in the soil compared to most of the target species (Bagi, 2008).

Most studies dealing with invasive plant species focus on negative consequences of invasion while positive or neutral impacts of invasive plants on native plant species had been frequently overlooked and rarely reported (Rodriguez, 2006). Our study is among the few that show non-negative effects of an invasive alien plant species on native grasslands (e.g. Meffin et al., 2010; Quinos et al., 1998). Davis et al. (2011) emphasize that it is crucial to gather sound evidence that a given non-native species causes any real harm to biodiversity before deciding to eradicate the species. Hobbs et al. (2009) suggest that some non-native species should be accepted as part of the ecosystem when eradication is not feasible.

Based on our results, alien common milkweed appears to be a "passenger' exotic species sensu MacDougall and Turkington (2005) as it did not suppress or exclude native species and can even slightly facilitate the regeneration of open sand grasslands. We suggest that it is not critical to control this species during the restoration of open sand grasslands. Furthermore, the eradication of this species is problematic as effective control methods cause soil disturbance in loose sandy soil (Bagi, 2008), which may enhance reinvasion by the same species and further invasion by other exotics (Zavaleta et al., 2001). Of course, the impacts of exotic species may change over time (Dostál et al., 2013) and future management decisions should consider these possible alterations.

\section{Conclusions}

Despite the presence of several land use legacies, we conclude that sand grasslands have a high restoration potential in burnt pine plantations, and our results have clear implications for improving the effectiveness of future restoration interventions. We showed that secondary pine litter from dead pine trees did not limit grassland recovery. Furthermore, we found no evidence that common milkweed would negatively affect grassland recovery, but had some positive effects on species composition, which indicates that a successful restoration of sand grasslands does not require the control of this alien species. Finally, seed addition of the dominant perennial grasses of the target grassland led to a fast establishment of the perennial grass matrix, with some negative effects on other species. These results suggest that the determination of appropriate seeding density of dominant grasses that does not suppress other target species should be a crucial component of an effective restoration intervention.

\section{Acknowledgements}

The editor and three anonymous referees provided valuable suggestions to improve the manuscript. The study was supported by the 
Hungarian Scientific Research Fund (OTKA 112576) and the MTA Bolyai Scholarship (G. K-D.). We thank Juliette Bloor for improving English.

\section{Appendix A. Supplementary data}

Supplementary data associated with this article can be found in the online version, at http://dx.doi.org/10.1016/j.biocon.2016.08.004. These data include the Google map of the most important areas described in this article.

\section{References}

Adams, C.R., Galatowitsch, S.M., 2008. The transition from invasive species control to native species promotion and its dependence on seed density thresholds. Appl. Veg. Sci. 11, 131-138.

Bagi, I., 2008. Common milkweed (Asclepias syriaca L.). In: Botta-Dukát, Z., Balogh, L. (Eds.), The Most Important Invasive Plants in Hungary. Institute of Ecology and Botany, Hungarian Academy of Sciences, Vácrátót, Hungary, pp. 151-159.

Bates, D., Maechler, M., Bolker, B., Walker, S., 2014. lme4: Linear Mixed-effects Models Using Eigen and S4. R Package Version 1. 1-7.

Becerra, P.I., Simonetti, J.A., 2013. Patterns of exotic species richness of different taxonomic groups in a fragmented landscape of central Chile. Bosque 34, 45-51.

Benjamini, Y., Hochberg, Y., 1995. Controlling the false discovery rate: a practical and powerful approach to multiple testing. J. Roy. Stat. Soc. 57, 289-300.

Bisteau, E., Mahy, G., 2005. Vegetation and seed bank in a calcareous grassland restored from a Pinus forest. Appl. Veg. Sci. 8, 167-174.

Boydak, M., 2004. Silvicultural characteristics and natural regeneration of Pinus brutia ten. - a review. Plant Ecol. 171, 153-163.

Bremer, L., Farley, K., 2010. Does plantation forestry restore biodiversity or create green deserts? A synthesis of the effects of land-use transitions on plant species richness. Biodivers. Conserv. 19, 3893-3915.

Catling, P.M., King, B., 2007. Natural recolonization of cultivated land by native prairie plants and its enhancement by removal of Scots pine, Pinus sylvestris. Can. Field Nat. 121, 201-205.

Corbin, J.D., D'Antonio, C.M., 2004. Can carbon addition increase competitiveness of native grasses? A case study from California. Restor. Ecol. 12, 36-43

Corbin, J.D., D'Antonio, C.M., 2012. Gone but not forgotten? Invasive plants' legacies on community and ecosystem properties. Invasive Plant Sci. Manage. 5, 117-124

R Core Team, 2012. R: A Language and Environment for Statistical Computing. R Foundation for Statistical Computing, Vienna, Austria (ISBN 3-900051-07-0).

Csecserits, A., Czúcz, B., Halassy, M., Kröel-Dulay, G., Rédei, T., Szabó, R., Szitár, K., TöröK, K., 2011. Regeneration of sandy old-fields in the forest steppe region of Hungary. Plant Biosyst. 145, 715-729.

Cseresnyés, I., Csontos, P., Bózsing, E., 2006. Stand age influence on litter mass of Pi nus nigra plantations on dolomite hills in Hungary. Can. J. Bot. 84, 363-370.

Cuevas, Y.A., Zalba, S.M., 2010. Recovery of native grasslands after removing invasive pines. Restor. Ecol. 18, 711-719.

Davis, M.A., Chew, M.K., Hobbs, R.J., Lugo, A.E., Ewel, J.J., Vermeij, G.J., Brown, J.H., Rosenzweig, M.L., Gardener, M.R., Carroll, S.P., 2011. Don't judge species on their origins. Nature 474, 153-154.

Dickie, I.A., St John, M.G., Yeates, G.W., Morse, C.W., Bonner, K.I., Orwin, K., Peltzer, D.A., 2014. Belowground legacies of Pinus contorta invasion and removal result in multiple mechanisms of invasional meltdown. AoB Plants 6, 1-15.

Dickson, T.L., Busby, W.H., 2009. Forb species establishment increases with decreased grass seeding density and with increased forb seeding density in a Northeast Kansas, USA, experimental prairie restoration. Restor. Ecol. 17, 597-605.

Dostál, P., Müllerová, J., Pyšek, P., Pergl, J., Klinerová, T., 2013. The impact of an invasive plant changes over time. Ecol. Lett. 16, 1277-1284.

Farley, K.A., Kelly, E.F., 2004. Effects of afforestation of a páramo grassland on soil nutrient status. For. Ecol. Manag. 195, 281-290.

Fekete, G., Tuba, Z., 1982. Photosynthetic activity in the stages of sandy succession. Acta Bot. Acad. Sci. Hung. 28, 291-296.

Foster, D., Swanson, F., Aber, J., Burke, I., Brokaw, N., Tilman, D., Knapp, A., 2003. The importance of land-use legacies to ecology and conservation. Bioscience $53,77-88$.

Funk, J.L., McDaniel, S., 2010. Altering light availability to restore invaded forest: the predictive role of plant traits. Restor. Ecol. 18, 865-872.

Gallé, R., Erdélyi, N., Szpisjak, N., Tölgyesi, C., Maák, I., 2015. The effect of the invasive Asclepias syriaca on the ground-dwelling arthropod fauna. Biologia $70,104-112$.
Gasque, M., Garciá-Fayos, P., 2004. Interaction between Stipa tenacissima and Pinus halepensis: consequences for reforestation and the dynamics of grass steppes in semi-arid Mediterranean areas. For. Ecol. Manag. 189, 251-261.

Habel, J.C., Dengler, J., Janišová, M., Török, P., Wellstein, C., Wiezik, M., 2013. European grassland ecosystems: threatened hotspots of biodiversity. Biodivers. Conserv. 22, 2131-2138

Halpern, C.B., Haugo, R.D., Antos, J.A., Kaas, S.S., Kilanowski, A.L., 2012. Grassland restoration with and without fire: evidence from a tree-removal experiment. Ecol. Appl. 22, 425-441.

Halpern, C.B., Antos, J.A., McKenzie, D., Olson, A.M., 2016. Past tree influence and prescribed fire mediate biotic interactions and community reassembly in a grassland-restoration experiment. J. Appl. Ecol. 53, 264-273.

Hobbs, R.J., Higgs, E., Harris, J.A., 2009. Novel ecosystems: implications for conservation and restoration. Trends Ecol. Evol. 24, 599-605.

Holmes, P.M., Richardson, D.M., Van Wilgen, B.W., Gelderblom, C., 2000. Recovery of South African fynbos vegetation following alien woody plant clearing and fire: implications for restoration. Austral Ecol. 25, 631-639.

Hothorn, T., Bretz, F., Westfall, P., 2008. Simultaneous inference in general parametric models. Biom. J. 50, 346-363.

Hulvey, K.B., Aigner, P.A., 2014. Using filter-based community assembly models to improve restoration outcomes. J. Appl. Ecol. 51, 997-1005.

Jiang, L., Han, X., Zhang, G., Kardol, P., 2010. The role of plant-soil feedbacks and land-use legacies in restoration of a temperate steppe in northern China. Ecol. Res. 25, 1101-1111.

Kelemen, A., Valkó, O., Kröel-Dulay, G., Deák, B., Török, P., Tóth, K., Miglécz, T., Tóthmérész, B., 2016. The invasion of common milkweed (Asclepias syriaca) in sandy old-fields-is it a threat to the native flora?. Appl. Veg. Sci. 19, 218-224.

Király, G. (Ed.), 2009. Új magyar Füvészkönyv. Magyarország hatásos növényei. [New Hungarian Herbal. The Vascular Plants of Hungary. Identification Key]. Aggtelek National Park Directorate, Jósvafó.

Kovács-Láng, E., Kröel-Dulay, G., Kertész, M., Fekete, G., Bartha, S., Mika, J., Dobi-Wantuch, I., Rédei, T., Rajkai, K., Hahn, I., 2000. Changes in the composition of sand grasslands along a climatic gradient in Hungary and implications for climate change. Phytocoenologia 30, 385-407.

Kröel-Dulay, G., Garadnai, J., Lhotsky, B., Kovács-Láng, E., 2008. The role of disturbances in sand grassland dynamics. In: Kovács-Láng, E., Molnár, E., Kröel-Dulay, G., Barabás, S. (Eds.), The Kiskun LTER: Long-term Ecological Research in the Kiskunság, Hungary. pp. 41-43.

Leege, L.M., Murphy, P.G., 2000. Growth of the non-native Pinus nigra in four habitats on the sand dunes of Lake Michigan. For. Ecol. Manag. 126, 191-200.

MacDougall, A.S., Turkington, R., 2005. Are invasive species the drivers or passengers of change in degraded ecosystems?. Ecology $86,42-55$.

Maestre, F.T., Cortina, J., 2004. Are Pinus halepensis plantations useful as a restoration tool in semiarid Mediterranean areas?. For. Ecol. Manag. 198, 303-317.

Maestre, F.T., Callaway, R.M., Valladares, F., Lortie, C.J., 2009. Refining the stress-gradient hypothesis for competition and facilitation in plant communities. J. Ecol. 97, 199-205

Meffin, R., Miller, A.L., Hulme, P.E., Duncan, R.P., 2010. Experimental introduction of the alien plant Hieracium lepidulum reveals no significant impact on montane plant communities in New Zealand. Divers. Distrib. 16, 804-815.

Mojzes, A., Kalapos, T., 2015. Plant-derived smoke enhances germination of the invasive common milkweed (Asclepias syriaca L.). Pol. J. Ecol. 63, 280-285.

Morris, L.R., Monaco, T.A., Sheley, R.L., 2014. Impact of cultivation legacies on rehabilitation seedings and native species re-establishment in Great Basin shrublands. Rangel. Ecol. Manag. 67, 285-291.

Naidoo, R., Balmford, A., Costanza, R., Fisher, B., Green, R.E., Lehner, B., Malcolm, T., Ricketts, T.H., 2008. Global mapping of ecosystem services and conservation priorities. Proc. Natl. Acad. Sci. U. S. A. 105, 9495-9500.

Navarro-Cano, J.A., Barberá, G.G., Ruiz-Navarro, A., Castillo, V.M., 2009. Pine plantation bands limit seedling recruitment of a perennial grass under semiarid conditions. J. Arid Environ. 73, 120-126.

Navarro-Cano, J.A., Barberá, G.G., Castillo, V.M., 2010. Pine litter from afforestations hinders the establishment of endemic plants in semiarid scrubby habitats of Natura 2000 Network. Restor. Ecol. 18, 165-169.

Navarro-González, I., Pérez-Luque, A.J., Bonet, F.J., Zamora, R., 2013. The weight of the past: land-use legacies and recolonization of pine plantations by oak trees. Ecol. Appl. 23, 1267-1276.

Nuñez, M.A., Raffaele, E., 2007. Afforestation causes changes in post-fire regeneration in native shrubland communities of northwestern Patagonia, Argentina. J. Veg. Sci. 18, 827-834.

Oksanen, J., Guillaume Blanchet, F.G., Kindt, R., Legendre, P., Minchin, P.R., O'Hara, R.B., Simpson, G.L., Sólymos, P., Stevens, M.H.H., Wagner, H., 2012. Vegan. Comm. Ecol. Package. R Package Version 2.0-5.

Ónodi, G., Altbacker, V., Aszalós, R., Botta-Dukát, Z., Hahn, I., Kertész, M., 2014 Long-term weather sensitivity of open sand grasslands of the Kiskunsag Sand Ridge forest-steppe mosaic after wildfires. Comm. Ecol. 15, 121-129. 
Pinheiro, J., Bates, D., DebRoy, S., Sarkar, D., the R Development Core Team, 2012. nlme: Linear and Nonlinear Mixed Effects Models. R Package Version. 3, 1-103.

Piqueray, J., Bottin, G., Delescaille, L.-M., Bisteau, E., Colinet, G., Mahy, G., 2011. Rapid restoration of a species-rich ecosystem assessed from soil and vegetation indicators: the case of calcareous grasslands restored from forest stands. Ecol. Indic. $11,724-733$.

Pykälä, J., 2003. Effects of restoration with cattle grazing on plant species composition and richness of semi-natural grasslands. Biodivers. Conserv. 12, 2211-2226.

Pywell, R.F., Pakeman, R.J., Allchin, E.A., Bourn, N.A.D., Warman, E.A., Walker, K.J., 2002. The potential for lowland heath regeneration following plantation removal. Biol. Conserv. 108, 247-258.

Quinos, P.M., Insausti, P., Soriano, A., 1998. Facilitative effect of Lotus tenuis on Paspalum dilatatum in a lowland grassland of Argentina. Oecologia 114, 427-431.

Richardson, D.M., Rejmánek, M., 2004. Conifers as invasive aliens: a global survey and predictive framework. Divers. Distrib. 10, 321-331.

Rodriguez, L.F., 2006. Can invasive species facilitate native species? Evidence of how, when, and why these impacts occur. Biol. Invasions 8, 927-939.
Sturgess, P., Atkinson, D., 1993. The clear-felling of sand-dune plantations: soil and vegetational processes in habitat restoration. Biol. Conserv. 66, 171-183.

Szitár, K., Ónodi, G., Somay, L., Pándi, I., Kucs, P., Kröel-Dulay, G., 2014. Recovery of inland sand dune grasslands following the removal of alien pine plantation. Biol. Conserv. 171, 52-60.

Taylor, B.R., Parkinson, D., Parsons, W.F.J., 1989. Nitrogen and lignin content as predictors of litter decay rates: a microcosm test. Ecology 70, 97-104.

Török, K., Botta-Dukát, Z., Dancza, I., Németh, I., Kiss, J., Mihály, B., Magyar, D., 2003. Invasion gateways and corridors in the Carpathian Basin: biological invasions in Hungary. Biol. Invasions 5, 349-356.

Walker, K.J., Pywell, R.F., Warman, E.A., Fowbert, J.A., Bhogal, A., Chambers, B.J., 2004. The importance of former land use in determining successful re-creation of lowland heath in southern England. Biol. Conserv. 116, 289-303.

Zaloumis, N.P., Bond, W.J., 2011. Grassland restoration after afforestation: no direction home?. Austral Ecol. 36, 357-366.

Zavaleta, E.S., Hobbs, R.J., Mooney, H.A., 2001. Viewing invasive species removal in a whole-ecosystem context. Trends Ecol. Evol. 16, 454- 459. 